\title{
Annonamine, a New Aporphine Alkaloid from the Leaves of Annona muricata
}

\author{
Ayano Matsushige, ${ }^{a}$ Yaichiro Kotake, ${ }^{a}$ Katsuyoshi Matsunami, ${ }^{b}$ Hideaki Otsuka, ${ }^{* b}$ \\ Shigeru Ohta, ${ }^{a}$ and Yoshio Takeda ${ }^{c}$
}

\begin{abstract}
${ }^{a}$ Department of Xenobiotic Metabolism and Molecular Toxicology, Graduate School of Biomedical Sciences, Hiroshima University; ${ }^{b}$ Department of Pharmacognosy, Graduate School of Biomedical Sciences, Hiroshima University; 1-2-3 Kasumi, Minami-ku, Hiroshima 734-8553, Japan: and ${ }^{c}$ Faculty of Pharmacy, Yasuda Women's University; 6-13-1 Yasuhigashi, Asaminami-ku, Hiroshima 731-0153, Japan.
\end{abstract}

Received September 7, 2011; accepted December 4, 2011; published online December 12, 2011

Atypical Parkinsonism in the Caribbean Island Guadeloupe is thought to be associated with the consumption of plants of the Annonaceae family, especially Annona muricata (soursop). In this study, a new aporphine alkaloid named annonamine (1) was isolated from the leaves of $A$. muricata $\mathrm{L}$. together with four known benzylisoquinoline alkaloids $(2-5)$. The structures of the isolated compounds were elucidated by the spectroscopic method.

Key words Annona muricata; Annonaceae; aporphine; alkaloid; annonamine

Parkinson's disease (PD) is a common neurodegenerative disorder. Over ten genes have been identified as causes of familial PD so far. ${ }^{1}$ However, in the case of idiopathic PD (accounting for over $90 \%$ of PD cases), endogenous and/or exogenous environmental factors are believed to be crucial for the onset of symptoms. ${ }^{2,3)}$ In 1999, Caparros-Lefebvre et al. suggested the high prevalence of atypical Parkinsonism in the Caribbean Island Guadeloupe was linked with consumption of Annonaceous fruits and herbal tea prepared from Annona muricata and $A$. squamosa. ${ }^{4}$ In 2005, Höglinger et al. described the neurotoxic effects of annonacin, the most abundant acetogenin in A. muricata, which inhibited the complex 1 of the mitochondrial respiratory chain. ${ }^{5)}$ On the other hand, we have previously identified 1-benzyl-1,2,3,4-tetrahydroisoquinoline (1BnTIQ) alkaloids as one of the endogenous neurotoxins that could induce PD in an animal model. ${ }^{6}$ In this study, we have phytochemically investigated the leaves of the title plant in detail to characterize the chemical constituents especially on alkaloids, because the leaves of $A$. muricata are used as tea for cardiotonics and it has been known that A. muricata produced benzylisoquinoline type alkaloids. ${ }^{7,8)}$ The present study describes the isolation and structural elucidation of a new aporphine alkaloid, annonamine (1) together with four known alkaloids (2-5). The neurotoxicities of these compounds (1-5) were also investigated against human neuroblastoma cell line, SH-SY5Y.

Air-dried leaves of $A$. muricata were extracted with $\mathrm{MeOH}$ three times by maceration. The combined $\mathrm{MeOH}$ extract was evaporated and partitioned with $n$-hexane, $\mathrm{CHCl}_{3}, \mathrm{EtOAc}$ and $1-\mathrm{BuOH}$ successively to give $n$-hexane, $\mathrm{CHCl}_{3}, \mathrm{EtOAc}$ and 1-BuOH-soluble fractions, respectively. $\mathrm{CHCl}_{3}$ and EtOAcsoluble fractions were combined because of the similarity of TLC pattern. The residue of $1-\mathrm{BuOH}$-soluble fraction and the combined mixture of $\mathrm{CHCl}_{3}$ and EtOAc-soluble fractions were subjected to various kinds of column chromatography (CC) to yield five alkaloids (1-5) (Fig. 1).

Annonamine (1) was obtained as a colorless amorphous powder and the high-resolution electrospray-ionization timeof-flight mass spectroscopy (HR-ESI-TOF-MS) provided the positive-ion peak at $m / z=296.1644$, which was corresponding to $\mathrm{C}_{19} \mathrm{H}_{22} \mathrm{NO}_{2}$. The IR absorption at $3360 \mathrm{~cm}^{-1}$ indicated the presence of hydroxy group. In the ${ }^{13} \mathrm{C}-\mathrm{NMR}$ spectrum, $12 s p^{2}$ carbon signals were ascribable to two aromatic rings. The substitution manners of each ring were determined by a coupling pattern analysis of five aromatic protons, of which a singlet aromatic proton $\left(\delta_{\mathrm{H}} 6.78\right)$, and four ortho- and meta-coupled protons $\left(\delta_{\mathrm{H}} 8.32,7.40,7.37,7.31\right)$ suggested the presence of penta-, and ortho-disubstituted aromatic rings, respectively (Table 1). Three downfield-shifted singlet methyl groups $\left(\delta_{\mathrm{H}}\right.$ 3.62 on $\delta_{\mathrm{C}} 60.8, \delta_{\mathrm{H}} 3.42$ on $\delta_{\mathrm{C}} 54.2$, and $\delta_{\mathrm{H}} 3.08$ on $\delta_{\mathrm{C}} 43.8$ ) were attributable to the $O$-methyl, $O$ - or $N$-methyl, and $N$ methyl groups, respectively. In the heteronuclear multiple bond connectivity (HMBC) spectrum, $\delta_{\mathrm{H}} 3.42$ and $\delta_{\mathrm{H}} 3.08$ were correlated with each other, which indicated the both methyl groups $\left(\delta_{\mathrm{H}} 3.42\right.$ on $\delta_{\mathrm{C}} 54.2$ and $\delta_{\mathrm{H}} 3.08$ on $\left.\delta_{\mathrm{C}} 43.8\right)$ were connected to the same hetero atom, i.e. nitrogen (Fig. 2 ). In addition, these two methyl groups were also correlated with both $\delta_{\mathrm{C}} 70.8$ and $\delta_{\mathrm{C}} 62.8$, which unveiled the presence of a quaternary amine in its structure (Fig. 2). The other methoxy group $\left(\delta_{\mathrm{C}} 60.8\right)$ must be located on $\mathrm{C}-1$, because of the relatively downfield-shifted chemical shift value caused by a steric effect of ortho-disubstitution. The contiguities of the remaining two methylenes $\left(\delta_{\mathrm{C}} 62.8,24.7\right)$, and a methylene and a methine $\left(\delta_{\mathrm{C}} 70.8,30.9\right)$ groups were also elucidated

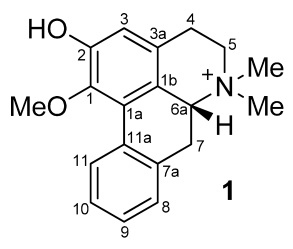<smiles>COc1ccc2c(c1O)-c1c(OC)ccc3c1[C@@H](C2)NCC3</smiles><smiles>c1ccc2c(c1)C[C@H]1NCCc3cc4c(c(c3-2)OCO4)N1</smiles><smiles>COc1ccc(C[C@H]2NCCc3cc(OC)c(OC)cc32)cc1</smiles>

Fig. 1. Structures of the Isolated Alkaloids 
Table 1. ${ }^{1} \mathrm{H}$ - and ${ }^{13} \mathrm{C}-\mathrm{NMR}$ Data for $\mathbf{1}$

\begin{tabular}{|c|c|c|}
\hline & $\mathrm{C}$ & $\mathrm{H}$ \\
\hline 1 & 146.9 & - \\
\hline 1a & 128.6 & - \\
\hline $1 b$ & 120.2 & - \\
\hline 2 & 152.9 & - \\
\hline 3 & 116.5 & $6.78 \mathrm{~s}$ \\
\hline $3 a$ & 126.2 & - \\
\hline 4 & 24.7 & $\alpha^{*} 3.02 \mathrm{~m}$ \\
\hline \multirow[t]{2}{*}{5} & 62.8 & $\begin{array}{c}\beta^{*} 3.34 \mathrm{~m} \\
\alpha^{*} 3.79 \text { ddd }(13, \\
7,1)\end{array}$ \\
\hline & & $\beta^{*} 3.73 \operatorname{td}(13,5)$ \\
\hline $6 a$ & 70.8 & $4.56 \mathrm{dd}(14,4)$ \\
\hline \multirow[t]{2}{*}{7} & 30.9 & $\alpha^{*} 3.05 \mathrm{~m}$ \\
\hline & & $\beta^{*} 3.37 \mathrm{~m}$ \\
\hline $7 \mathrm{a}$ & 133.5 & - \\
\hline 8 & 129.4 & $7.40 \mathrm{~d}(7)$ \\
\hline 9 & 129.5 & $7.31 \mathrm{td}(7,1)$ \\
\hline 10 & 129.2 & 7.37 brt (8) \\
\hline 11 & 129.1 & $8.32 \mathrm{dd}(8,1)$ \\
\hline $11 \mathrm{a}$ & 132.5 & \\
\hline $\mathrm{O}-\mathrm{Me}$ & 60.8 & $3.62(3 \mathrm{H}, \mathrm{s})$ \\
\hline $\mathrm{N}^{+}-\mathrm{Me} \alpha^{*}$ & 43.8 & $3.08(3 \mathrm{H}, \mathrm{s})$ \\
\hline $\mathrm{N}^{+}-\mathrm{Me} \beta^{*}$ & 54.2 & $3.42(3 \mathrm{H}, \mathrm{s})$ \\
\hline
\end{tabular}

Measured in $\mathrm{CD}_{3} \mathrm{OD} . \delta$ in ppm. ${ }^{*}$ The orientations were determined by phasesensitive nuclear Overhauser exchange spectroscopic analysis.

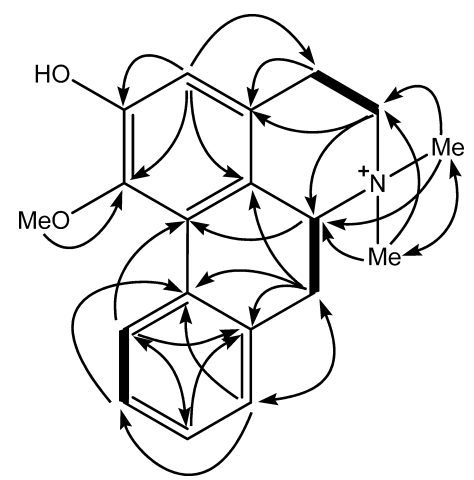

Fig. 2. Important Correlations on COSY (Bold Lines) and HMBC (Arrows)

by double-quantum-filtered ${ }^{1} \mathrm{H}-{ }^{1} \mathrm{H}$ correlation spectroscopy (COSY) and hetero-nuclear multiple quantum coherence spectra (Fig. 2). The planer structure was elucidated as shown in Fig. 2 by the detailed analysis of 2D-NMR spectra. Finally, the absolute stereochemistry of C-6a was determined to be $R$ by the circular dichroism (CD) spectrum. ${ }^{9)}$ Thus, the structure of 1 was elucidated as $(R)$-2-hydroxy-1-methoxy-6,6-dimethyl5,6,6a,7-tetrahydro-4H-dibenzo[de,g]quinolin-6-ium.

$\mathrm{PD}$ is a common neurodegenerative disorder marked by progressive loss of melanized, catecholamine producing neurons in the midbrain (substantia nigra) and brain stem (locus ceruleus). Therefore, we next evaluated the neurotoxicity against the human neuroblastoma SH-SY5Y which is a well-characterized catecholaminergic cell line often used as a neuronal model in PD research. Among the tested compounds (1-5), compound $\mathbf{3}$ was the most active $\left(\mathrm{IC}_{50}\right.$ for 1: 195.8 $\pm 17.0,2$ : 186.6 \pm 29.4, 3: $34.6 \pm 3.5,4: 97.1 \pm 11.2$, 5: $202.9 \pm 9.9 \mu \mathrm{M})$.
In this study, we have successfully isolated a new aporphine alkaloid together with four known benzylisoquinoline alkaloids from the leaves of $A$. muricata. It is noteworthy that anonaine (3) has been reported to inhibit dopamine biosynthesis at $0.05 \mu \mathrm{m}$ by mainly reducing tyrosine hydroxylase activity in rat stable pheochromocytoma cells, PC12. ${ }^{10)}$ In this study, we presented the moderate neurotoxicity of $\mathbf{3}$ against SH-SY5Y. Thus, anonaine (3) might affect the development of the idiopathic atypical Parkinson's disease in the Caribbean Island Guadeloupe by inhibiting the dopamine biosynthesis at lower dose and by the neurotoxicity at higher dose. We are now planning to investigate the detailed biological function of these alkaloids on the several protein molecules concerning for the development of Parkinson's disease.

\section{Experimental}

General Experimental Procedures Silica gel CC was performed on silica gel 60 (Merck, Darmstadt, Germany), and reversed-phase [octadecyl silica gel (ODS)] open CC (RPCC) on Cosmosil $75 \mathrm{C}_{18}$-OPN (Nacalai Tesque, Kyoto, Japan) $(\Phi=4 \mathrm{~cm}, L=20 \mathrm{~cm})$. HPLC was performed on ODS (Cosmosil; Nacalai Tesque, Japan; $\Phi=10 \mathrm{~mm}, L=250 \mathrm{~mm}$ ), and the eluate was monitored with a refractive index monitor.

Optical rotations were measured on a JASCO P-1030 polarimeter. IR spectrum was measured on a Horiba FT-710 Fourier transform infrared spectrophotometer. UV spectrum was obtained on a JASCO V-520 UV/Vis spectrometer. NMR spectra were taken on a JEOL ECA 600 spectrometer at $600 \mathrm{MHz}$ for ${ }^{1} \mathrm{H}$ and $150 \mathrm{MHz}$ for ${ }^{13} \mathrm{C}$, respectively, with tetramethylsilane as an internal standard. Positive-ion HR-ESITOF-MS was recorded on an Applied Biosystem QSTAR XL spectrometer. CD spectra were obtained on a JASCO J-720 spectropolarimeter. VersaMax (Molecular Devices, Sunnydale, CA, U.S.A.) was used as a microplate reader.

Plant Material Leaves of $A$. muricata were collected in Okinawa, Japan, in November, 2004, and a voucher specimen was deposited in the Herbarium of the Department of Pharmacognosy, Graduate School of Biomedical Sciences, Hiroshima University (No. 04-a.m.-Okinawa-1105).

Extraction and Isolation The air-dried leaves of $A$. $m u$ ricata $(520 \mathrm{~g})$ were extracted with $\mathrm{MeOH}(2 \mathrm{~L})$ three times by maceration. The $\mathrm{MeOH}$ extracts were combined and evaporated to dryness to afford a viscous gummy material $(78.2 \mathrm{~g})$. This residue was suspended in $1.5 \mathrm{~L}$ of $\mathrm{H}_{2} \mathrm{O}$ and extracted with equal volume of $n$-hexane, $\mathrm{CHCl}_{3}$, EtOAc and 1 - $\mathrm{BuOH}$ successively to afford $13.4,34.9,1.1$ and $5.0 \mathrm{~g}$ of the residues, respectively. The remaining $\mathrm{H}_{2} \mathrm{O}$ layer was concentrated to furnish an $\mathrm{H}_{2} \mathrm{O}$-soluble fraction $(23.9 \mathrm{~g})$. The $1-\mathrm{BuOH}$ soluble fraction $(5.0 \mathrm{~g})$ was applied to a silica gel $\mathrm{CC}(\Phi=2.5 \mathrm{~cm}, L=50 \mathrm{~cm})$ using a stepwise gradient elution with increasing amounts of $\mathrm{MeOH}$ in $\mathrm{CHCl}_{3}\left[\mathrm{CHCl}_{3}(1 \mathrm{~L}), \mathrm{CHCl}_{3}-\mathrm{MeOH}(20: 1\right.$, $750 \mathrm{~mL}),(10: 1,750 \mathrm{~mL}),(5: 1,750 \mathrm{~mL})$, and $(3: 1,750 \mathrm{~mL})]$, $\left(\mathrm{CHCl}_{3}: \mathrm{MeOH}: \mathrm{H}_{2} \mathrm{O}=15: 6: 1,750 \mathrm{~mL}\right)$, and $(\mathrm{MeOH}, 750 \mathrm{~mL})$. The residue $(1.13 \mathrm{~g})$ of the $\mathrm{CHCl}_{3}: \mathrm{MeOH}: \mathrm{H}_{2} \mathrm{O}=15: 6: 1$ eluate obtained on silica gel CC was subsequently purified by HPLC (ODS) with $20 \% \mathrm{CH}_{3} \mathrm{CN} / 0.1 \%$ trifluoroaceteric acid (TFA) to afford $1(25.8 \mathrm{mg}$ ) from the peak at $20.2 \mathrm{~min}$ (flow rate: $3.0 \mathrm{~mL} / \mathrm{min}$ ).

The combined residue of $\mathrm{CHCl}_{3}$ and EtOAc soluble fractions $(36.0 \mathrm{~g})$ was applied to a silica gel CC $(\Phi=5.8 \mathrm{~cm}, L=38 \mathrm{~cm})$ using a stepwise gradient elution with increasing amounts of 
$\mathrm{MeOH}$ in $\mathrm{CHCl}_{3}\left[\mathrm{CHCl}_{3}(3 \mathrm{~L}), \mathrm{CHCl}_{3}-\mathrm{MeOH}(100: 1,3 \mathrm{~L})\right.$, $(50: 1,3 \mathrm{~L}),(30: 1,3 \mathrm{~L}),(20: 1,3 \mathrm{~L})(10: 1,3 \mathrm{~L}),(5: 1,3 \mathrm{~L})$, and $(2: 1,3 \mathrm{~L})]$, and $(\mathrm{MeOH}, 5 \mathrm{~L})$. The residue $(7.36 \mathrm{~g})$ of the $\mathrm{CHCl}_{3}: \mathrm{MeOH}=10: 1$ eluate obtained on silica gel $\mathrm{CC}$ was subsequently subjected to RPCC with a stepwise gradient elution with increasing amounts of $\mathrm{MeOH}$ in $\mathrm{H}_{2} \mathrm{O}(30,50,70$, 90, $100 \% \mathrm{MeOH}, 300 \mathrm{~mL}$ containing with $0.1 \%$ TFA). The residues $(190 \mathrm{mg})$ obtained from $50 \% \mathrm{MeOH}$ eluate was purified by HPLC (ODS) with $30 \%$ acetone $/ 0.1 \%$ TFA to afford $\mathbf{5}$ $(10.3 \mathrm{mg}$ ) from the peak at $10.4 \mathrm{~min}$ (flow rate: $2.8 \mathrm{~mL} / \mathrm{min}$ ). The residue $(5.95 \mathrm{~g})$ of the $\mathrm{CHCl}_{3}: \mathrm{MeOH}=5: 1$ eluate obtained on silica gel CC was subsequently subjected to RPCC with a stepwise gradient elution with increasing amounts of $\mathrm{MeOH}$ in $\mathrm{H}_{2} \mathrm{O}(30,50,70,90,100 \% \mathrm{MeOH}, 300 \mathrm{~mL}$ containing with $0.1 \%$ TFA). The residues $(170 \mathrm{mg}$ ) obtained from $30 \% \mathrm{MeOH}$ eluate was purified by HPLC (ODS) with $20 \% \mathrm{CH}_{3} \mathrm{CN} / 0.1 \%$ TFA to afford $2(4.9 \mathrm{mg}$ ) from the peak at $17.9 \mathrm{~min}$ (flow rate: $2.5 \mathrm{~mL} / \mathrm{min})$. The residues $(220 \mathrm{mg})$ obtained from $50 \% \mathrm{MeOH}$ eluate was purified by HPLC (ODS) with $30 \%$ acetone $/ 0.1 \%$ TFA to afford $4(7.0 \mathrm{mg})$ and $3(5.3 \mathrm{mg})$ from the peaks at 5.2 and $14.6 \mathrm{~min}$, respectively (flow rate: $2.8 \mathrm{~mL} / \mathrm{min}$ ).

The known compounds $(\mathbf{2}-\mathbf{5})$ were identified by comparison of spectroscopic data with those reported in the literature as follows. $(S)$-Norcorydine $(2)^{11)} \quad$ ref. $[\alpha]_{\mathrm{D}}^{23}+190 \quad(c=0.2$, $\left.\left.\mathrm{CHCl}_{3}\right)\right\},[\alpha]_{\mathrm{D}}^{22}+151 \quad\left(c=0.13, \mathrm{CHCl}_{3}\right), \mathrm{CD} \Delta \varepsilon(\mathrm{nm}):-7.81$ $(268),+43.0 \quad(234) \quad\left(c=3.98 \times 10^{-5} \mathrm{M}, \mathrm{MeOH}\right), \quad(R)$-anonaine $(3)^{12)}\left\{\right.$ ref. $\left.[\alpha]_{\mathrm{D}}^{20}-48\left(c=0.1, \mathrm{CHCl}_{3}\right)\right\},[\alpha]_{\mathrm{D}}^{22}-34.9(c=0.10$, $\left.\mathrm{CHCl}_{3}\right), \mathrm{CD} \Delta \varepsilon(\mathrm{nm}):+11.4(271),-52.5(231)\left(c=3.08 \times 10^{-5} \mathrm{M}\right.$, $\mathrm{MeOH}),(R)-4^{\prime}-O$-methylcoclaurine $(4),{ }^{13)}[\alpha]_{\mathrm{D}}^{22}+14.5(c=0.19$, $\left.\mathrm{CHCl}_{3}\right), \mathrm{CD} \Delta \varepsilon(\mathrm{nm}):-1.09(288),-1.75(230)\left(c=3.18 \times 10^{-5} \mathrm{M}\right.$, $\mathrm{MeOH}),(R)-O, O$-dimethylcoclaurine $(5)^{14)}$ \{ref. $[\alpha]_{\mathrm{D}}^{25}+15.7$ $\left.\left(c=0.4, \mathrm{CHCl}_{3}\right)\right\},[\alpha]_{\mathrm{D}}^{21}+10.9\left(c=0.16, \mathrm{CHCl}_{3}\right), \mathrm{CD} \Delta \varepsilon(\mathrm{nm})$ : -1.15 (288), $-2.00 \quad(232) \quad\left(c=2.59 \times 10^{-5} \mathrm{M}, \mathrm{MeOH}\right)$. Other chemical constituents including megastigmane glucosides have been isolated previously and published elsewhere. ${ }^{15)}$

Annonamine (1): Amorphous powder; $[\alpha]_{\mathrm{D}}^{22}-12.5(c=1.70$, $\mathrm{MeOH}$ ); IR $v_{\max }$ (film) $\mathrm{cm}^{-1}: 3360,2964,2937,1680,1431$, 1354, 1259, 1200, 1183, 1136, 1007, 798; UV $\lambda_{\max }(\mathrm{MeOH})$ $\mathrm{nm}(\log \varepsilon): 310 \mathrm{sh}$ (3.16), 283sh (3.76), 273 (3.90), 229 (3.99), 211 (4.15); ${ }^{1} \mathrm{H}$ - and ${ }^{13} \mathrm{C}-\mathrm{NMR}\left(\mathrm{CD}_{3} \mathrm{OD}\right)$ : Table 1 ; CD $\Delta_{\varepsilon}(\mathrm{nm})$ : +0.86 (274), -6.15 (233) $\left(c=5.43 \times 10^{-5} \mathrm{M}, \mathrm{MeOH}\right)$; HR-ESITOF-MS (positive-ion mode) $\mathrm{m} / \mathrm{z}: 296.1644[\mathrm{M}]^{+}$(Calcd for $\mathrm{C}_{19} \mathrm{H}_{22} \mathrm{NO}_{2}$ : 296.1645).

Cytotoxicity Assay The cytotoxicity assay was performed using human neuroblastoma cell line, SH-SY5Y by 3-[4,5-dimethylthiazol-2-yl]-2,5-diphenyltetrazolium bromide (MTT) method. In brief, cells $\left(5 \times 10^{3}\right.$ cells $/ 100 \mu \mathrm{L}$ complete medium $)$ were cultured in 96-well plates with different concentrations of the test compounds (200-6.25 $\mu \mathrm{m} ; 1 \%$ of dimethyl sulfoxide (DMSO) was present as a vehicle in all the experiments) for $72 \mathrm{~h}$ at $37^{\circ} \mathrm{C}$. Then the culture supernatants were replaced with
$100 \mu \mathrm{L}$ of a MTT solution comprising $0.5 \mathrm{mg} / \mathrm{mL}$ of MTT in complete medium. After $3 \mathrm{~h}$ incubation at $37^{\circ} \mathrm{C}$, the precipitate was dissolved in $100 \mu \mathrm{L}$ of DMSO. The optical density values for each well were measured at $520 \mathrm{~nm}$ with a microplate reader.

The cytotoxicity was calculated using the following equation:

$$
\text { Inhibition } \left.(\%)=\left[1-\left(A_{\text {sample }}-A_{\text {background }}\right) / A_{\text {DMSO }}-A_{\text {background }}\right)\right] \times 100
$$

where $A_{\text {DMSO }}$ is the absorbance of the control reaction mixture (containing DMSO and all reagents except for the test compound).

Acknowledgments The authors are grateful for access to the superconducting NMR instrument (JEOL ECA-600) and the Applied Biosystem QSTAR XL system ESI (Nano Spray) mass spectrometer at the Natural Science Center for Basic Research and Development (N-BARD), Hiroshima University. This work was supported in part by Grants-in-Aid from the Ministry of Education, Culture, Sports, Science and Technology of Japan (Nos. 22590006 and 23590130), and the Ministry of Health, Labour and Welfare. Thanks are also due to the Research Foundation for Pharmaceutical Sciences and the Takeda Science Foundation for the financial support.

\section{References}

1) Shulman J. M., De Jager P. L., Feany M. B., Annu. Rev. Pathol., 6 , $193-222$ (2011).

2) Allam M. F., Del Castillo A. S., Navajas R. F., Neurol. Res., 27, 206-208 (2005).

3) Shaw C. A., Höglinger G. U., Neuromolecular Med., 10, 1-9 (2008).

4) Caparros-Lefebvre D., Elbaz A., Lancet, 354, 281-286 (1999).

5) Höglinger G. U., Michel P. P., Champy P., Feger J., Hirsch E. C., Ruberg M., Lannuzel A., Mov. Disord., 20, 118-119 (2005).

6) Kotake Y., Tasaki Y., Makino Y., Ohta S., Hirobe M., J. Neurochem., 65, 2633-2638 (1995).

7) Fofana S., Ziyaev R., Abdusamatov A., Zakirov S. K., Chem. Nat. Compd., 47, 321 (2011).

8) Leboeuf M., Legueut C., Cavé A., Desconclois J. F., Forgacs P., Jacquemin H., Planta Med., 42, 37-44 (1981).

9) Ringdahl B., Chan R. P. K., Craig C., Cava M. P., Shamma M., J. Nat. Prod., 44, 80-85 (1981).

10) Lee J. J., Jin C. M., Kim Y. K., Ryu S. Y., Lim S. C., Lee M. K., Molecules, 13, 475-487 (2008).

11) Shafiee A., Jafarabadi A. H., Planta Med., 64, 489 (1998).

12) Wu Y. C., Heterocycles, 29, 463-475 (1989).

13) Chaves M. H., Santos L. A., Lago J. H. G., Roque N. F., J. Nat. Prod., 64, 240-242 (2001).

14) Pedrosa R., Andrés C., Iglesias J. M., J. Org. Chem., 66, 243-250 (2001).

15) Matsushige A., Matsunami K., Kotake Y., Otsuka H., Ohta S., J. Nat. Med., in press. 